\title{
FORMS OF HAND IN SIGN LANGUAGE IN BOSNIA AND HERZEGOVINA
}

\section{Husnija Hasanbegović ${ }^{1}$ \\ Esad H. Mahmutović \\ Admira Beha}

Original scientific paper
Faculty of Education and Rehabilitation, University of Tuzla
Center for Education and Rehabilitation of hearing and speech, Tuzla

Received: 08.02.2013

Accepted: 12.04.2013
UDC:81'221.24(497.6)

\begin{abstract}
Sign in sign language, equivalent to the word, phrase or a sentence in the oral-language, can be divided in linguistic units of lower levels: shape of the hand, place of articulation, type of movement and orientation of the palm. The first description of these units, which today is present and applicable in Bosnia and Herzegovina (B\&H), was given by Zimmerman in 1986, who found 27 shapes of hand, while other types were not systematically developed or described. The target of this study was to determine the possible existence of other forms of hand movements present in sign language in $B \& H$. By the method of content analysis, the 425 analyzed signs in sign launguage in $B \& H$, confirmed their existence, but we also discovered and presented 14 new shapes of the hand. This way, we confirmed the need of implementing a detailed research, standardization and publishing of sign language in $B \& H$, which would provide adequate conditions for its study and application, as for the deaf, and all the others who come into direct contact with them.
\end{abstract}

Key words: sign, sign launguage in $B \& H$, forms of hand

\section{INTRODUCTION}

Sign language of the deaf is a separate language system, characteristic for his population, independent of the oral-language of the national community in which they exist.

Previous studies of sign language in Bosnia and Herzegovina $(\mathrm{B} \& \mathrm{H})$, have been mainly related to its recognition in the education of the deaf, that is, its role within bilingual access to educational and rehabilitation process. Research of Kasumović, Hasanbegović (2005), focused on stressing the role of hand alpha- bet, as programmed computer letters, in the communication of the deaf, while research Kurtagić (2005), points out to the difficulties and problems in communication of hearing impaired children and their parents. Hasanbegović (2006), through the application of newly constructed rehabilitation programs and the use of programmed two-handed letters indicates the advantage of hearing these letters over the Latin block alphabet.

\footnotetext{
${ }^{1}$ Correspodence to:

Husnija Hasanbegović, Faculty of Education and Rehabilitation, University of Tuzla

Branilaca Banovića 76. Banovići, B\&H

Phone: +38761739089

E-mail: husnijamaj@hotmail.com
} 
Affirmation of sign language in $\mathrm{B} \& \mathrm{H}$ has also been contributed to by the research conducted by Salkić, Mahmutović and Mujkanović within their papers for Masters degree in the 2008, which thoroughly analyzed the status and position of deaf people in $\mathrm{B} \& \mathrm{H}$ in relation to the means of communication. Although there are no extensive and exact linguistic researches it can be concluded that the sign language in $\mathrm{B} \& \mathrm{H}$ has an unique grammatical structure, but that there are some regional differences, mainly in the so-called lexic, or so called "phonological", or vizem interpretation of individual characters.

Sign in sign language is equivalent to a word in the oral-spoken language, but it can also be equivalent to a whole phrase or a sentence. They are based on the visual perception (vizema), i.e., they represent a link between the concept or phenomenon (marked) and a hand movement (gestures), an expression (signal) of the face and movement of a part or of a whole body (signifier). One sign, most often, is a combination of these movements, and less often, a carrier of meaning that occurs isolated (Mahmutović, 2008).

As in oral language, where a word can be divided into smallest distinctive units - phonemes, so can any sign of sign language be broken down to a lower level language units. These least distinctive units of sign language, William Stokoe in 1965. called "cheremes" (BradarićJončić, 2000). Stokoe has portrayed each character as a combination consisting of cheremes, where he showed that any two characters in sign language differ in at least one linguistic unit (chereme). According to him, there are three types of linguistic elements: hand shapes, movement and place of articulation. He described a total of 55 cherema, 18 types of hand shapes, 12 places of articulation and 25 types of movement. To this division later was added the fourth type of element, palm orientation.

The first description of linguistic units of signs in sign language, in the former Yugoslav regions, was given by Zimmerman in 1986, where he identified 27 shapes of hand, and other types of units that he did not systematically develop ${ }^{2}$. This description or representation has to this date been present in Bosnia and Herzegovina's educational and rehabilitation literature and applicable in theory and practice.

Aim: To investigate shapes of the hand sign language in $\mathrm{B} \& \mathrm{H}$, and specify the names of possibly newly discovered shapes of the hand and accompany them with words in which they are presented.

\section{METHODS}

\section{Test materials}

Test materials consisted of a total of 425 videos, and also as many photos and drawings of characters from the sign language used in $\mathrm{B} \& \mathrm{H}$.

\section{Data collection methods}

Information on the shapes of the hand sign language in B \& H were collected using content analysis, whereby the analyzed video footage (recorded, according to previously established list of words, in direct contact with deaf people on the field), and photos and drawings from the dictionary for the deaf related to the same characters.

Analysis is carried out by an expert team of professionals: linguists, author of dictionaries, two surdoaudiologists, one deaf person who uses oral spoken language, and an interpreter and certified translator for sign language (native speaker - a child of deaf parents).

The collected data was systematized in the form constructed to determine the linguistic components of sign language, that is, the determination of the hand shape, place of articulation movement, type of movement, and palm orientation. Variables allocated for this study were divided into two groups, first one consisted of earlier discovered shapes of hand: flat palm, spoon, collected fingers, broken palm, claw, spread palm, clenched fist, fist A, fist $\mathrm{O}$, middle finger, index finger, thumb, fist $\mathrm{U}$, fist $\mathrm{L}$, little finger , flying fists, clothespin, fist $\mathrm{V}$, crest, fist 4 , little $\mathrm{C}$, the big $\mathrm{C}$, small beak, beak $\mathrm{U}$, large beak, clips, double clips, and second one of newly discovered shapes of hand that were later identified.

\section{Methods of data processing}

For the data processing we used descriptive analysis,we calculated the frequencies and percentages and presented it in a form of a table. After that, we named the newly found hand shapes and gave examples of the words in which they are used.

${ }^{2}$ Kasumović, A., Hasanbegović, H. (2002). SUGOSG BIH. (2005 \& 2007) 


\section{RESULTS AND DISCUSSION}

Table 1 outlines presentation of shapes of hand sign language in B \& $\mathrm{H}$, the 425 analyzed characters, where we noted that, out of 500 present shapes of hand, to previously discovered shapes of hands belong 455 shapes or $91 \%$, and to the newly discovered shapes belongs the total of 45 shapes or $9 \%$. Disproportion in the number of characters and the total number of hand shapes is reflected in the fact that the performance of certain characters needs the use of both hands with different shapes of hand.

The total number of newly discovered shapes of the hand (41) makes up 14 new different forms. These results confirm the hypothesis that the sign language in $\mathrm{B} \& \mathrm{H}$ uses more shapes of the hand than it has been presented in the literature. It can be concluded that the previously known shapes of the hand (27 forms), used in surdoaudiologist educational and rehabilitation science, and theory and practice in $\mathrm{B} \& \mathrm{H}, 14$ newly shaped hands, give added value to the recognition of sign language, but also show the necessity for a detailed research, standardization and publication of the sign language and the creation of conditions that contribute to the achievement of all the needs of education, the realization of other rights, and generally improvement of the quality of life for the deaf.

Table 1 Presentation of the shapes of hand sign language in $B \& H$

\begin{tabular}{lcc}
\hline \multicolumn{1}{c}{ Forms fist } & $\mathrm{f}$ & $\%$ \\
\hline $\begin{array}{l}\text { Previously discovered shapes of the hand }(27 \\
\text { forms) }\end{array}$ & 455 & 91 \\
The newly discovered shapes of the hand & 45 & 9 \\
TOTAL & 500 & 100 \\
\hline
\end{tabular}

Newly discovered shapes of the hand, in accordance with the needs and requirements of the linguistics, and by association with the author, have been given the following names: hand small $\mathrm{O}$, triple clip, collected three fingers, hand flash, crooked fingers, spread crooked fingers, big beak U, small beak U, a small claw, hand $\mathrm{E}$, middle $\mathrm{O}$, hand marble, hand 4 spread, and middle C. Given the application of scientific methods, we feel that it is justificated to point out certain signs of sign language in $\mathrm{B} \& \mathrm{H}$ in which these shapes appear to be recognized:

Hand small O: a pill, a day, better, a round button;

Triple clip: BMW car;

Collected fingers 3: experience, why;

Hand flash: to throw, flowers, spring, to smell;

Crooked fingers: camera, to escape;

Spread crooked fingers: stingy, nervous;

Big beak U: inside, archives, soft, wet;

Small beak U: small, blueberries;

Small claw: Vienna;

Hand E: euro, email, error, to hope;
Middle O: street, quickly, when, Africa, to reject; Hand marble: a detail, a whatnot, a marble, grain; Hand 4 spread: Croatia, hedgehog, crossword puzzles, fan;

Middle C: headache, doctor, sore throat, Greece (Kasumović, Hasanbegović 2002; SUGOSG 2005 \& 2007).

\section{CONCLUSION}

Sign language of the deaf in $\mathrm{B} \& \mathrm{H}$ is an unique language system, whose linguistic structure is not known, and in this regard, this study shows that only through a comprehensive research, systematization, standardization and publication of studies, appropriate steps will be made for its comprehensive learning and application. The survey defined only certain new shapes of the hand, which lead to the resolution of very complex problems related to the standardization of sign language in $\mathrm{B} \& \mathrm{H}$, but an opening has been created that require other similar studies. 


\section{REFERENCES}

Bradarić-Jončić, S. (2000). Manuelna komunikacija osoba oštećena sluha. Hrvatska revija za rehabilitaacijska istraživanja. 36 (2) $123-136$.

Hasanbegović, H. (2006). Rehabilitacijski programi u jezičkom razvoju gluhih. Doctoral dissertation. Univerzity of Tuzla. ERF Tuzla.

Kasumović, A., Hasanbegović, H. (2002). Rječnik za gluhe. Tuzla: JU narodna i Univerzitetska biblioteka "Derviš Sušić" Tuzla.

Kasumović, A., Hasanbegović, H. (2005). Programirano pismo kao podrška jezičkom razvoju gluhih. Zbornik radova. 31 (6). 115-119. Filozofski fakultet. Univerzity of Tuzla.

Kurtagić, I. (2005). Teškoće i problemi u komunikaciji slušno oštećene djece i njihovih roditelja u Bosni i Hercegovini. Mostovi. 18/19. 22-25. SUGOSG.
Mahmutović, E. (2008). Teorijske i praktične osnove za formiranje bosanskog znakovnog jezika. Master thesis. Univerzity of Tuzla. ERF Tuzla.

Mujkanović, E., (2008). Znakovni jezik u funkciji prevazilaženja socijalno-komunikacijskih barijera. Master thesis. Univerzity of Tuzla. ERF Tuzla.

Salkić, N., (2008). Gluhi između oralizma i znakovnog jezika. Master thesis. Univerzity of Tuzla. ERF Tuzla.

SUGOSG BIH. (2005). Govorite li znakovni?. Sarajevo: SUGOSIG BIH, Centar za tumače znakovnog jezika.

SUGOSG BiH. (2007). Govorite li znakovni?. Sarajevo: SUGOSIG BIH, Centar za tumače znakovnog jezika.

Zimmerman, A. (1986). Uvodni seminar o komunikaciji s osobama oštećena sluha. Zagreb: Savez osoba oštećena sluha grada Zagreba. 